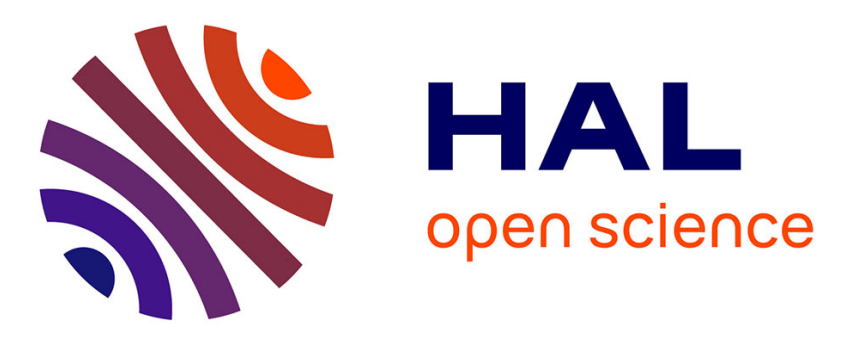

\title{
Effect of indoleamine 2,3-dioxygenase expressed by foetal fibroblasts on melanoma cells
}

Cécile Frenard, Anne-Chantal Knol, Marie Lemoigne, Amir Khammari, Brigitte Dreno

\section{- To cite this version:}

Cécile Frenard, Anne-Chantal Knol, Marie Lemoigne, Amir Khammari, Brigitte Dreno. Effect of indoleamine 2,3-dioxygenase expressed by foetal fibroblasts on melanoma cells. Experimental Dermatology, 2016, 25, pp.822 - 824. 10.1111/exd.13058 . inserm-01409073

\section{HAL Id: inserm-01409073 https://www.hal.inserm.fr/inserm-01409073}

Submitted on 5 Dec 2016

HAL is a multi-disciplinary open access archive for the deposit and dissemination of scientific research documents, whether they are published or not. The documents may come from teaching and research institutions in France or abroad, or from public or private research centers.
L'archive ouverte pluridisciplinaire HAL, est destinée au dépôt et à la diffusion de documents scientifiques de niveau recherche, publiés ou non, émanant des établissements d'enseignement et de recherche français ou étrangers, des laboratoires publics ou privés. 


\section{References}

1 Schallreuter $\mathrm{K} U$, Hasse $\mathrm{S}$, Rokos $\mathrm{H}$ et al. Exp Dermatol 2009: 18: 680-688.

2 Endo A, Kuroda M, Tanzawa K. FEBS Lett 1976 72: 323-326.

3 Galus R, Niderla J, Sladowski D et al. Pharmacol Rep 2010: 62: 164-169.
4 Galus R, Wlodarski K, Malejczyk J et al. Int J Mo Sci 2013: 14: 14333-14345.

5 Lee J, Lee J, Jung $\mathrm{E}$ et al. Food Chem Toxicol 2013: 51: 225-230.

6 Yamaguchi Y, Hearing V J. BioFactors 2009: 35 193-199.
7 Busca R, Ballotti R. Pigment Cell Res 2000: 13 : $60-69$.

8 Jin $\mathrm{S} \mathrm{H}$, Lee $Y \mathrm{Y}$, Kang $\mathrm{H}$ Y. Arch Dermatol Res 2008: 300: 451-454.

9 Rai S K, Sharma M, Tiwari M. Life Sci 2009: 85: 211-219.

\title{
Effect of indoleamine 2,3-dioxygenase expressed by foetal fibroblasts on melanoma cells
}

\author{
Cécile Frenard ${ }^{1}$, Anne-Chantal Knol ${ }^{2,3}$, Marie Lemoigne ${ }^{1}$, Amir Khammari ${ }^{1}$ and Brigitte Dreno ${ }^{1}$ \\ ${ }^{1}$ Skin cancer unit, Nantes University Hospital, Nantes, France; ${ }^{2} \mathrm{CHU}$, immunodermatology lab, Hôtel Dieu, Nantes, France; ${ }^{3}$ Inserm, CRCNA \\ U892, Hôtel Dieu, Nantes, France \\ Correspondence: Brigitte Dreno, Skin cancer unit, Nantes University Hospital, 1 place Alexis Ricordeau, 44000 Nantes, France, Tel.: +33 240083118, \\ Fax: +332400848 06, e-mail: brigitte.dreno@wanadoo.fr
}

Key words: indoleamine 2,3-dioxygenase - melanoma - fetal fibroblasts

Accepted for publication 25 April 2016

\section{Background}

Tumor cells escape the immune system by creating immune tolerance in the environment around the tumor. This is currently a major issue in the treatment of melanoma by immunotherapy with monoclonal antibodies (anti-CTLA4/PD1 antibody), vaccines and tumor-infiltrating lymphocytes (TILs) (1).

IDO is an intra-cellular enzyme that degrades tryptophan to kynurenine, inducing a local immunosuppression through deficiency in the amino acid, which is needed for the T cells' activity (2).

In melanoma, IDO has been shown to be increased in both primary and metastatic lesions and its expression correlated with increased invasiveness and disease progression rate (3-5).

IDO thus appears to be a molecule that may play a major role in the induction of immune tolerance of melanoma cells via the microenvironment. However, until now, we have still few information on the interaction between IDO and melanoma cells.

It has been shown that normal fibroblasts in tumors can affect tumor cell growth. Fibroblasts have also been reported to have foetal fibroblasts characteristics (6).

As our team developed foetal fibroblast lines expressing both isoforms of IDO at a high level (7), we created an in vitro model closed to in vivo microenvironment permitting to study the interactions between melanoma cells and IDO.

\section{Questions addressed}

The primary objective of the study was to investigate the modulations induced in melanoma cells by IDO produced by foetal fibroblasts.

\section{Experiment design}

The melanoma cells were cocultured with foetal fibroblasts. To confirm the specificity of the action of IDO, 1-methyl-L-tryptophan (1MT) (20 mm solution, $\mathrm{pH} 9-10$ ) was added to the culture medium under the various conditions at D0 at the concentration of $500 \mu \mathrm{M}$.
Testing was conducted at time point 24 and $48 \mathrm{~h}$; five cell lines were studied for all the parameters investigated and nine cell lines for PD-L1. Flow cytometry was conducted on melanoma cells with membrane labelling for PD-L1, PD-L2, MHC I, MHC II and intracellular labelling for gp100, Melan-A and tyrosinase. ProcartaPlex Luminex Human kits (eBioscience) were used to determine the TGF- $\beta$, IL- $1 \beta$ and IL-10 concentrations in the culture media under the various conditions. The IDO activity in the culture was evaluated by determining the kynurenine/tryptophan ratio using an ELISA test (LDN). Full experimental procedure is available in the supplemental methods section (Appendix S1).

\section{Results}

IDO activity measuring by kynurenine/tryptophane ratio

The higher the kynurenine/tryptophan ratio was, the higher was the tryptophan catabolism activity, reflecting the activity of IDO1, IDO2 and TDO2.

The analysis showed that co-incubation between fibroblasts and melanoma cells resulted in higher tryptophan degradation in the culture medium than tumor cells alone $(P=0,009)$. Tryptophan degradation activity was inhibited by 1-MT, a specific IDO inhibitor, confirming the specificity of the results and that the increase in tryptophan degradation activity in the presence of foetal keratinocytes and fibroblasts was IDO dependent (Fig 1a).

PD-L1 modulation induced by IDO

Two types of modulation were induced by cocultivating the melanoma cells with fibroblasts (Fig 2):

- For five cell lines, an induction of the expression of PD-L1 by the melanoma cells (M241 + 44\%, M284 + 42\%, M301 + 64\%, M305 + 14\% and M254 + 8\%) was observed.

- For four cell lines (M113, M212, M373 and M387), the expression of PD-L1 was not induced on melanoma cells by the 

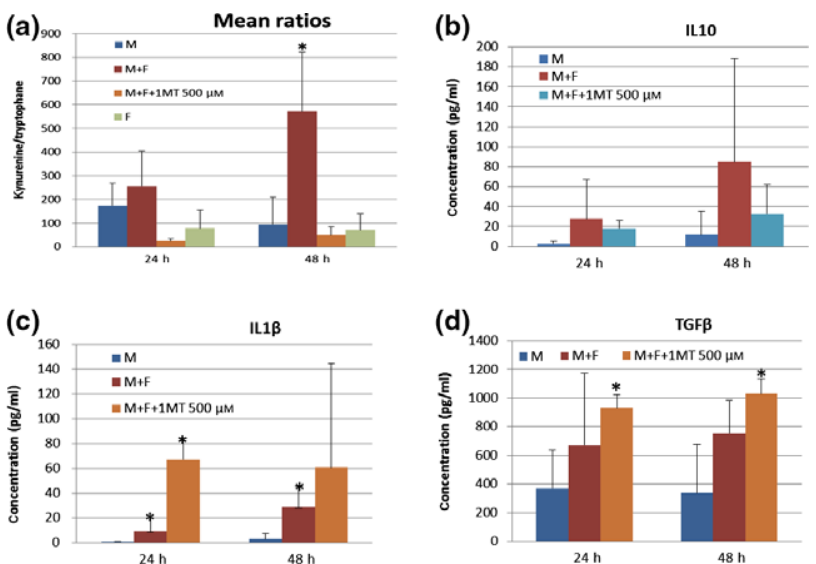

Figure 1. (a) Mean kynurenine/tryptophan ratios in the culture media supernatants. $* P<0.05$. (b) $\| \mathrm{L}-10$ concentrations in culture medium supernatants. $* P<0.05$. (c) IL-1 $\beta$ concentrations in culture medium supernatants. $* P<0.05$. (d) TGF- $\beta$ concentrations in culture medium supernatants. $* P<0.05$. F, foetal fibroblasts; K, foetal keratinocytes; M, melanoma cells, for the five cell lines.

coculture with foetal fibroblasts. Addition of 1-MT to the culture medium completely inhibited $(>95 \%)$ the PD-L1 expression in cell lines M254, M284, M301 and M305 and partially inhibited it $(<50 \%)$ in cell line M241 confirming that IDO was directly implicated in the modulation of PD-L1 by the melanoma cells.

In contrast, PD-L2 expression was not induced in the melanoma cells by 3 of the 5 cell lines studied and only weakly induced by cell lines M284 and M301 ( $<2 \%$ fluorescent cell). PD-L2 was not modulated by the foetal fibroblasts.

Increase in cytokines concentration in coculture supernatants

IDO-positive fibroblasts increased the secretion of IL- $1 \beta(<5 \mathrm{pg} /$ $\mathrm{ml}$ at $10 \mathrm{~h}, 30 \mathrm{pg} / \mathrm{ml}$ at 24 and $48 \mathrm{~h}, P>0.05$ ), by melanoma cell in the medium culture, and the secretion of IL-10, by melanoma cells increased $(<5 \mathrm{pg} / \mathrm{ml}$ at $10 \mathrm{~h}, 25 \mathrm{pg} / \mathrm{ml}$ at $24 \mathrm{~h}$ and $80 \mathrm{pg} / \mathrm{ml}$ at $48 \mathrm{~h}$ ) and in addition TGF- $\beta$ also increased $(380 \mathrm{pg} / \mathrm{ml}$ at $10 \mathrm{~h}, 650 \mathrm{pg} / \mathrm{ml}$ at $24 \mathrm{~h}$ and $750 \mathrm{pg} / \mathrm{ml}$ at $48 \mathrm{~h}$ ) (Fig $1 \mathrm{~b}-\mathrm{d}$ ).

However, for the three cytokines, the increase of secretion in the culture medium was not inhibited by 1-MT.

Modulations of melanoma antigens and MHC

The induction of the expression of melanoma antigens, gp100, Melan-A and tyrosinase by melanoma cells incubated with fibroblasts was variable according to the melanoma cell line and not inhibited by $1-\mathrm{MT}$.

In the same manner, IDO-positive foetal fibroblasts did not induce any change in MHC I expression by the melanoma cells. MHC II expression was only decreased after coculturing with foetal fibroblasts for cell line M373 (-22\%).

Flow cytometry results are available in supplementary material.

\section{Conclusions}

This study showed the induction of PD-L1 expression by melanoma cells via the expression of IDO by fibroblasts cocultivated in the microenvironment. This induction of PD-L1 by IDO may contribute to inhibit the efficacy of adoptive cell therapy using TILs

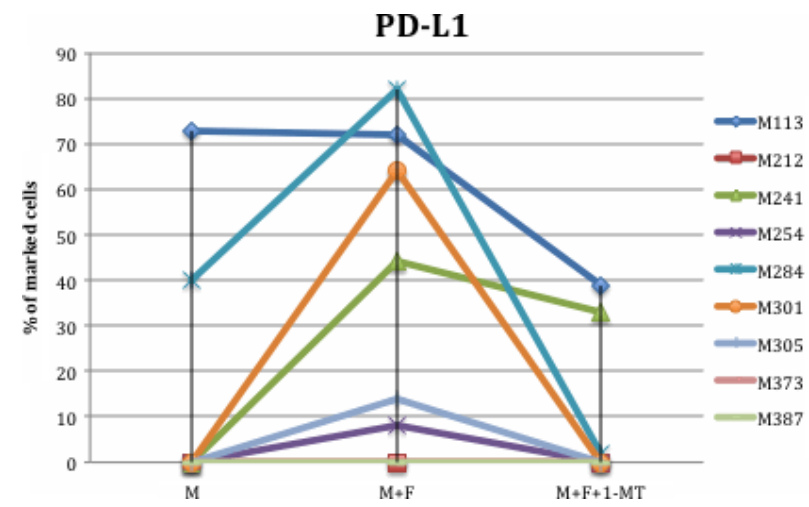

Figure 2. PD-L1 expression by melanoma cells evidenced by flow cytometry. F, foetal fibroblasts, K, keratinocytes; M, smelanoma cells.

by inducing inactivation of lymphocytes, decreasing both their survival and proliferation. It has been shown that melanoma cell PD-L1 expression greater than $5 \%$ is a predictive factor for response to treatment with anti-PD1 antibodies (8). IDO inhibitors could thus potentiate the efficacy of TILs and other immunotherapies by acting on the microenvironment and PD-L1 expression.

This preliminary study was performed with five cell lines for which all the parameters have been investigated and nine cell lines investigated for PD-L1 expression. Nonetheless, the results were homogeneous for the induction of PD-L1 expression and the degradation of tryptophan by foetal fibroblasts cocultured with melanoma cells.

A phase I/II study of combined ipilimumab and indoximod (medicinal form of 1-MT) at an oral dosage of $25 \mathrm{mg}$ or $300 \mathrm{mg}$ twice daily versus. placebo has been conducted. The disease control rate for the indoximod combination was $75 \%$ (9).

\section{Acknowledgements}

The authors thank Thomas Zuliani for initiating the foetal cell lines.

\section{Author contributions}

Cecile Frenard and Anne-Chantal Knol performed the research; Brigitte Dreno, Amir Khammari, Cecile Frenard and Anne-Chantal Knol designed the research study; Cecile Frenard, Anne-Chantal Knol, Marie Lemoigne, Amir Khammari and Brigitte Dreno contributed essential reagents or tools; Cecile Frenard, Anne-Chantal Knol and Marie Lemoigne analysed the data; and Cecile Frenard and Brigitte Dreno wrote the manuscript.

\section{Conflict of interests}

The authors have declared no conflicting interests.

\section{Supporting Information}

Additional Supporting Information may be found online in the supporting information tab for this article:

Appendix S1. Supplementary material and methods.

Table S1. Characteristics of the melanoma cell lines.

Table S2. Flow cytometry antibodies.

Figure S1. Flow cytometry results for melanoma cell line M241 at time points 24 and 48 hours $(\mathrm{M}=$ melanoma cells, $\mathrm{F}=$ fibrobalsts, $1 \mathrm{MT}=1$-Methyltryptophan $)$.

Figure S2. Flow cytometry results for melanoma cell line M284 at time points 24 and 48 hours $(\mathrm{M}=$ melanoma cells, $\mathrm{F}=$ fibrobalsts, $1 \mathrm{MT}=1$-Methyltryptophan $)$.

Figure S3. Flow cytometry results for melanoma cell line M301 at time points 24 and 48 hours $(\mathrm{M}=$ melanoma cells, $\mathrm{F}=$ fibrobalsts, $1 \mathrm{MT}=1$-Methyltryptophan $)$.

Figure S4. Flow cytometry results for melanoma cell line M305 at time points 24 and 48 hours $(\mathrm{M}=$ melanoma cells, $\mathrm{F}=$ fibrobalsts, $1 \mathrm{MT}=1$-Methyltryptophan $)$.

Figure S5. Flow cytometry results for melanoma cell line M373 at time points 24 and 48 hours $(\mathrm{M}=$ melanoma cells, $\mathrm{F}=$ fibrobalsts, $1 \mathrm{MT}=1$-Methyltryptophan $)$. 


\section{References}

1 Polak M E, Borthwick N J, Gabriel F G, et al. Br J Cancer 2007: 96: 1879-1887.

2 Munn D H, Shafizadeh E, Attwood J T, et al. J Exp Med 1999: 189: 1363-1372.

3 Chevolet I, Speeckaert $\mathrm{R}$, Haspeslagh $\mathrm{M}$, et al. $\mathrm{Br}$ J Dermatol 2014: 171: 987-995.
4 Speeckaert $\mathrm{R}_{\mathrm{r}}$ Vermaelen $\mathrm{K}$, van Geel $\mathrm{N}_{\text {s }}$ et al. Eur J Cancer 1990: 2012(): 2004-2011.

5 Brody J R, Costantino C L, Berger A C, et al. Cell Cycle 2009: 8: 1930-1934.

6 Cornil I, Theodorescu D, Man S, et al. Proc Nat Acad Sci USA 1991: 88: 6028-6032.
7 Zuliani T, Saiagh S, Knol A-C et al. PLOS ONE 2013: 8: e70408.

8 Topalian S L, Hodi F S, Brahmer J R, et al. N Engl J Med 2012: 366: 2443-2454.

9 Vacchelli $\mathrm{E}$, Aranda F, Eggermont A, et al. Oncoimmunology 2014: 3: e957994.

\title{
Menthoxypropanediol inhibits nerve growth factor-induced nerve fibre sprouting in coculture models of sensory neurons and skin cells
}

\author{
Dennis Roggenkamp, Anne-Christin Worthmann, Melanie Sulzberger, Horst Wenck, Franz Stäb and \\ Gitta Neufang \\ Beiersdorf AG, Research Skin Care, Hamburg, Germany \\ Correspondence: Dr. Gitta Neufang, Beiersdorf AG, Hamburg, Germany, Tel.: +49 404909 6676, Fax: +49 404909 186676, Unnastraße 48, 20253 \\ Hamburg, Germany e-mail: gitta.neufang@beiersdorf.com
}

\begin{abstract}
Abbreviations: $\mathrm{AD}$, atopic dermatitis; CGRP, calcitonin gene-related peptide; CPC, capsaicin; DRG, dorsal root ganglion; MPD, menthoxypropanediol; $\mathrm{NF} \kappa \mathrm{B}$, nuclear factor 'kappa-light-chainenhancer' of activated B cells; NGF, nerve growth factor; TNF- $\alpha$, tumor necrosis factor- $\alpha$; TRP, transient receptor potential ion channel.
\end{abstract}

Key words: atopic dermatitis - hyperinnervation - itch - TRPM8 Accepted for publication 25 April 2016

\section{Background}

Atopic dermatitis (AD) is a chronic, relapsing and highly pruritic inflammatory skin disease affecting $10-20 \%$ of children and $2-5 \%$ of adults in developed countries $(1,2)$. In $\mathrm{AD}$, inflammation is related to an elevated skin cell-derived release of nerve growth factor (NGF), leading to an increased density of cutaneous C-fibres $(3,4)$ that might be linked to pruritus (5). Cooling agents, such as menthol or icilin, suppress itch by activating transient receptor potential ion channel M8 (TRPM8) on cutaneous A $\delta$ fibres $(6,7)$ and have therefore been used as an antipruritic treatment for many years (8). Additionally, TRPM8 activation has recently been shown to attenuate inflammatory responses in a mouse model of colitis (9). A potential anti-inflammatory effect of cooling agents and its impact on itch-associated hyperinnervation in AD had not been studied.

\section{Question addressed}

In this study, we investigate the role of menthoxypropanediol (MPD) in modulating inflammatory NGF upregulation and itchassociated hyperinnervation in coculture models of sensory neurons and skin cells.

\section{Experimental design}

Methods are presented in supplementary material.

\section{Results and discussion}

In the pathogenesis of $\mathrm{AD}, \mathrm{TNF}-\alpha$ acts synergistically with Th2 cytokines via $\mathrm{NF} \kappa \mathrm{B}$ to promote inflammatory processes [s1-s3]. In a screening, we identified the menthol derivative MPD (Fig. 1a,b) as a potent inhibitor of TNF- $\alpha$-induced NF $\kappa$ B activation (Fig. 1d).
This effect might be TRPM8 independent as menthol activated TRPM8 to the same extent as MPD (Fig. 1c), but did not modulate $\mathrm{NF} \kappa \mathrm{B}$ activation (Fig. 1d). In accordance with our findings, Ramachandran et al. observed a potent anti-inflammatory response with TRPM8 agonist icilin, but not with menthol (9). These findings indicate different mechanisms of cooling agents to modulate anti-inflammatory signalling that requires further investigation.

In $\mathrm{AD}$, pruritus is associated with elevated cutaneous levels of NGF and an increased intra-epidermal nerve fibre density [s4, s5]. Because of the fact that NGF is regulated by $\mathrm{NF} \kappa \mathrm{B}$ [s6], we hypothesized that MPD modulates NGF expression in skin cells. As TNF- $\alpha$ is known to upregulate NGF in an NF $\kappa$ B-dependent manner [s7] and is reported as an aggravation factor in atopic skin [s1], we treated dermal fibroblasts with TNF $\alpha$ and MPD. In fact, MPD reduced TNF- $\alpha$-induced upregulation of $n g f$ mRNA (Fig. 1e) and NGF protein (Fig. 1f), suggesting an impact of MPD on the regulation of cutaneous innervation. The TRPM8 antagonist AMTB did not abrogate the effect of MPD on $n g f$ regulation (Fig. S1) pointing to a TRPM8-independent mechanism.

To investigate whether the effect of MPD on NGF expression influences neurite outgrowth in vitro, we used our compartmented coculture model of porcine DRG neurons and dermal fibroblasts (Fig. 2). The model enables a culture of dermal fibroblasts with nerve endings spatially compartmented from DRG somata (Figs $\mathrm{S} 2$ and 2e). To mimic itch-associated hyperinnervation, we treated fibroblasts with histamine, inducing an increased outgrowth of 